\title{
Electromagnetic fields and public health
}

Recent years have witnessed an unprecedented increase in the number and diversity of sources of electromagnetic fields (EMF) used for individual, industrial and commercial purposes. Television, radio, computers, mobile cellular phones, microwave ovens, radar, and equipment used in industry, medicine, and commerce are just some of these sources. They have made our life richer and easier. Modern society is inconceivable without computers, television, and radio. Mobile phones have greatly enhanced communication between individuals and have facilitated the dispatch of emergency medical and police aid to persons in both urban and rural environments. Radar makes air travel much safer. At the same time, there is concern about possible health risks associated with the use of these and other technologies that utilize EMF.

Human-made EMF associated with these uses belong to that part of the electromagnetic spectrum called non-ionizing radiation (NIR) because its photon energies are too weak to break atomic bonds. They include ultraviolet (UV) radiation, visible light, infrared radiation, radiofrequency (RF) and microwave fields, extremely low frequency fields (ELF), and static electric and magnetic fields.

Some scientific studies have implicated RF waves associated with modern technologies in increased risks of cancer, particularly in children. Evidence has been adduced suggesting that environmental exposures to these fields may cause memory loss, reduced fertility, and adverse changes in the behavior and development of children. To date, epidemiologic studies attempting to confirm such an association have yielded inconsistent results, partly because of differences in design, execution, and method of interpretation. Potential RF associations with disease must be investigated until they are either established or disproved.

RF fields are known to affect human cells and tissues in various ways, depending on their frequencies. RF with frequencies less than 1 megahertz (the frequencies associated with AM radio, video monitors and display units, and some industrial induction heaters) can induce electric currents in tissues. RF between 1 megahertz and 10 gigahertz (associated with some industrial induction heaters, RF heat sealers, FM radio, mobile telephones, television broadcasts, microwave ovens, and medical diathermy) penetrate through the skin and heat internal tissues via energy absorption. RF higher 
than 1 gigahertz (in radar, microwave communications, and sunlight) are absorbed at the skin surface. The biological responses to these impacts have been variously reported to include changes in electrical activity in animal brains through changed calcium ion activity and alterations in cell proliferation rates, enzyme activities, and gene behavior.

ELF electric and magnetic fields are present, respectively, wherever an electric charge is present and wherever an electric current is flowing. Like $R F$, they have been associated in some studies with increased cancer risks, particularly in children. As in the case of RF, other studies have not found such an association.

Static electric fields do not penetrate into the body, although they can be perceived by skin hair movement. Except for electrical discharges from strong static electric fields, they do not seem to have significant health effects. Static magnetic fields have virtually the same strength inside the body as outside. Very intense static magnetic fields can alter blood flow or change normal nerve impulses, but such high field strengths are not found in everyday life. Nevertheless, there is insufficient information about the effects of long-term exposure to static magnetic fields at levels found in the working environment.

In light of the inconclusive state of knowledge of the health significance of EMF, WHO has launched the International EMF Project. Over the coming five years, the Project is charged with providing authoritative and independent peer-review of the scientific literature on biological effects of EMF, identifying and filling gaps in scientific knowledge by establishing protocols for the conduct of research using compatible and comparable methodologies, and encouraging more focused research that should lead to better health risk assessments in the EMF domain.

At a working meeting in Vienna, held 22-25 October 1997, Project manager Michael Repacholi stated, "Health research in this area has been largely ad hoc and totally uncoordinated at the international level. As a result, the picture of possible adverse effects from EMF exposure is incomplete, which has given rise to a combination of both real and perceived fears."

Experts at the meeting urged scientists, governments, and industry to learn to communicate more effectively concerning potential and real health impacts of EMF, and to be aware of psychological aspects that can distort realistic concerns into unrealistic fears in the minds of the public. Individ- uals' perceptions of risk can depend on their age, sex, and cultural and educational backgrounds. They are likely to be greater when the individuals cannot control their exposure, feel that it is unfair for them to be exposed, or do not personally benefit from the generation of the EMF-for example, if they live near a mobile telephone base station but do not own a mobile telephone.

The Project is overseen by an International Advisory Committee (IAC) consisting of representatives of international organizations, independent scientific institutions, and supportive national governments. All activities are coordinated and facilitated by the WHO Secretariat. The scientific work is conducted by the International Commission on Non-ionizing Radiation Protection (ICNIRP), which has previously established international guidelines on human exposure limits for all EMF, together with independent WHO scientific collaborating institutions. These latter include National Radiological Protection Board (UK), Bundesamt für Strahlenschutz (Germany), Karolinska Institute (Sweden), Food and Drug Administration (USA), National Institute of Environmental Health Sciences (USA), National Institute of Occupational Safety and Health (USA), and National Institute for Environment Studies (Japan).

\section{SINOPSIS}

\section{Campos electromágneticos y salud pública}

Recientemente han proliferado notablemente tanto el número como la diversidad de fuentes de campos electromagnéticos que se usan en el hogar, la industria y el comercio. Estas fuentes, como la televisión, las computadoras, el radar y los innumerables y complejos equipos que se usan en la medicina y otros campos, han enriquecido y mejorado nuestro estilo de vida. Sin embargo, algunos estudios científicos parecen indicar que la exposición ambiental a ondas radioeléctricas aumenta el riesgo de cáncer, reduce la fecundidad, produce pérdida de la memoria y afecta adversamente al comportamiento y el desarrollo de los niños. Los conocimientos sobre el tema se han reunido ad hoc y son sumamente escasos, por lo cual en octubre de 1997 la OMS lanzó un proyecto de 5 años para coordinar una investigación internacional al respecto. 